\title{
GONTOR AS THE LEARNING CONTEMPORARY ISLAMIC INSTITUTION TRANSFORMATION TOWARD THE MODERNITY
}

\author{
Muhammad Iqbal Fasa \\ Universitas Islam Negeri (UIN) Sunan Kalijaga Yogyakarta \\ Jl. Laksda Adisucipto Yogyakarta \\ Email: muhammadiqbalfasa@ymail.com
}

\begin{abstract}
Darussalam gontor modern islamic boarding school is one that is very instrumental in indonesia education coloring even southeast asia. There are five philosophical education of darussalam gontor modern islamic institution: the vision; the missions; the mottoes; the five spirits; and the long-term plan. This research attempts to offer darussalam gontor modern islamic institution transformation toward the modernity includes several things, first, based on total quality control second, based on cadre recruitment; third, based on teaching 24 hours.

Pondok Pesantren Modern Darussalam gontor adalah salah satu lembaga pendidikan yang sangat berperan dalam mewarnai pendidikan Indonesia bahkan asia tenggara. Ada lima filosofi pendidikan Pondok Pesantren Modern Darussalam gontor: visi; Misi; Motto; Lima roh; dan rencana jangka panjang. Penelitian ini mencoba menawarkan transformasi institusi Pondok Pesantren Modern Darussalam menuju lembaga pendidikan modern meliputi: pertama, berdasarkan total quality control; kedua, berdasarkan rekrutmen kader; ketiga, berdasarkan pengajaran 24 jam
\end{abstract}

Key Word: philosophical education, transformation, modernity

DOI: http:// dx.doi.org/ 10.24239/ jsi.v14i1.462.141-174

\section{Introduction}

Development of Islamic boarding school seen from the side of its history can be referred to as one of the oldest Islamic institution in Indonesia. Islamic boarding school appeared 
simultaneously with the process of Islamization that is happening on the Earth Indonesia in the 8th century and 9th century, and continues to evolve to the present time. The resilience showed boarding school throughout its history in addressing the times shows as an education. ${ }^{1}$

Islamic Boarding schools with different expectations and a predicate attached to him, indeed culminate in three main functions, namely: first, as a center of religious thinkers other cadre (Center of Excellence). Second, as the agency that prints human resources (Human Resource). Third, as the institutions that have the power of doing on empowerment of communities (Agent of Development). ${ }^{2}$

In the era of free competition, the development of the competence and capacity of the students is a compulsory matter. To be able to compete competitively in a global world, Islamic boarding schools are required capable of bearing products and alumni who have competency and productive in three things. First, a competent and prolific spiritually. Second, competent and socially productive. Third, the alumni of the seminary should be competent and productive economically. ${ }^{3}$ The thing that led to the change of the traditional boarding Islamic schools boarding school headed to boarding school.

Islamic boarding school in the future not only of text understanding Jurisprudence oriented exclusively, but more than that directed at the holistic paradigm of Jurisprudence, namely the new thinking that covers all aspects of life that are included in the level of a nation and a country practically. Furthermore, the boarding school as a cultural force is required constantly

\footnotetext{
${ }^{1}$ Abdul Mu'in, Pengembangan Ekonomi Pondok Pesantren (Jakarta: Prasasti IKAPI, 2007). 16.

2Suhartini, "Problem Kelembagaan Pengembangan Ekonomi Pesantren," in Manajemen Pesantren, ed. Pustaka Pesantren (Yogyakarta: LKIS, 2009). 233.

${ }^{3}$ Harjito, "Studi Potensi Ekonomi Dan Kebutuhan Pondok Pesantren Se Karesidenan Kedu Jawa Tengah," Jurnal Fenomena 6, no. 1 (2008): 1-19.
} 
responding to changes that are occurring. On the life of boarding schools, the students are trained to live together 24 hours per day. Thus was formed the soul of independence and a strong sense of community. ${ }^{4}$

The existence of Islamic boarding schools and the community are the two sides that cannot be separated, because both influence each other. The majority of Islamic boarding school developed from the existence of community support, and simply appearing or boarding establishment is an initiative of the community either individually or collectively. ${ }^{5}$

The role of the Islamic boarding school as a social institution was made the footing to make the boarding school as a change agent (agent of change) of the surrounding community, as intermediary institutions who are expected to serve as a catalyst for community development and dinamisator in the village, not only the religious field but also in the fields of social, economic and cultural. ${ }^{6}$

The purpose of Islamic boarding schools education is to create and develop the personality of the Muslims, that the personality of the faith and piety to God, adopting noble, beneficial to society, able to stand on its own, free and fast in the personality, to proselytise or to uphold Islam and the triumph of the people at the center of the community and loved science in order to develop the human personality. ${ }^{7}$

${ }^{4}$ Proyek Pembinaan dan Bantuan Kepada Pondok Pesantren, Pedoman Penyelenggaraan Unit Ketrampilan Pondok Pesantren (Jakarta: Ditjen Binbaga Islam Departemen Agama RI, n.d.). 3.

${ }^{5}$ Bahri Ghazali, Pendidikan Pesantren Berwawasan Lingkungan (Jakarta: Pedoman IImu Jaya, 2001). 13.

6 Irchamni Sulaiman, "Pesantren Mengembangkan Teknologi Tepat Guna ke Pedesaan," in Pergulatan Dunia Pesantren: Membangun dari Bawah, ed. M. Dawam Rahardjo (Jakarta: P3M, 1985). 246.

${ }^{7}$ Mujamil Qomar, Pesantren dari Transformasi Metodologi Menuju Demokratisasi Institusi (Jakarta: Erlangga, 2002). 4. 
The purpose of the Islamic boarding schools education exist around the formation of human beings that have extended our awareness guidance of Islam, the question of the meaning of life (weltanschaung) that is thorough, and is equipped with the extended ability to hold respond against challenges and the demands of life in the context of space and time exist: Indonesia and the world a century now. ${ }^{8}$ Based on the purpose of Islamic boarding school education that had been featured previously, Amin Haedari posited, there are three boarding school principal functions, namely: Transmission of Islamic Knowledge; Maintenance of Islamic Tradition; and Reproduction of Ulama. ${ }^{9}$

\section{Prototype of Islamic Boarding School Education in Indonesia}

A discussion of the Islamic boarding school in Indonesia society needs to be preceded by a discussion of the history of society's social structure as well as Indonesia. In the history of Indonesia Indonesia has occurred pre or meetings and cultural competition of India (the Indian-Buddhist), Arab (Islam), China, and the West (especially the Netherlands). In the course of its history, the influence of Islam varies depending of the existence of the State (the Kingdom) while it was in power. In many areas that still have a Kingdom with a strong Hindu influence that synergize with the local culture, such as Java, then the dynamics of the rivalry as well as the cooperation of both the combined pattern. ${ }^{10}$

The origins of the boarding school can not be separated from the history of the influence of the Wali Sanga of Java in the 15-16 century. Islamic boarding school is a unique Islamic institution in

\footnotetext{
${ }^{8}$ Nurcholis Madjid, "Merumuskan Kembali Tujuan Pendidikan Pesantren," in Pergulatan Dunia Pesantren: Membangun dari Bawah, ed. M. Dawam Rahardjo (Jakarta: P3M, 1985). 8.

${ }^{9}$ Amin Haedari, Masa Depan Pesantren: dalam Tantangan Modernitas dan Tantangan Komplesitas Global (Jakarta: IRD Press, 2004). 198.

${ }^{10}$ Iwan Gardono, Pesantren dan Demokrasi Jejak Demokrasi dalam Islam (Jakarta: Titian Pena, 2010). 3.
} 
Indonesia. The institution has grown especially in Java for centuries. Maulana Malik Ibrahim (died 1419 in Gresik, East Java), Spiritual father Wali Sanga, santri Javanese community is usually viewed as the teacher-the teacher of tradition of Islamic boarding school in Java. ${ }^{11}$

Cultivation of cultural values and traditions that make this institution, Islamic boarding school scored immoral people (akhlakul karimah) as well as giving teachings that are manifesting in sincerity, sincerity, independence, by, and courage. ${ }^{12}$

Islamic boarding school can live and thrive in the midst of Indonesia society. Among them there have been hundreds of years old, such as Islamic boarding school of Salafiah Darus Salihin is located in Tempelsari, times-Rows East Java founded in 1364. Al-Sumberadi Cave Islamic boarding school in Kebumen, Central Java the year 1600, the seminary Darul Muttaqin in Losari Central Java lived about the year $1648 .^{13}$

The development of the seminary began to appear in the early 20th century was marked by the opening of the madrasah system with the support of the scholars who recently returned from Mecca. ${ }^{14}$ Modern means of boarding boarding school that always responds to changes and demands of the times, forward-

\footnotetext{
${ }^{11}$ Abdurrahman Mas'ud, Dinamika Pesantren dan Madrasah (Yogyakarta: Pustaka Pelajar, 2002). 3.

${ }^{12}$ Saefuddin Zuhri et al., Pesantren Masa Depan : Wacana Pemberdayaan Dan Transformasi Pesantren, ed. Said Aqiel Siradj (Bandung: Pustaka Hidayah, 1999). 134.

${ }^{13}$ Hasan M. Ali, et al. Kapita Selekta Pendidikan Agama Islam (Jakarta: Pedoman IImu Jaya, 2003). 93.

${ }^{14}$ Baroroh Kirorom, "Pendidikan Formal Di Lingkungan Pesantren Sebagai Upaya Meningkatkan Kualitas Sumber Daya Manusia," Jurnal Ekonomi \& Pendidikan 3, no. 1 (2006): 42-52.
} 
looking, always give priority to the principle of effectiveness and efficiency as well as satisfying the people. ${ }^{15}$

The development of the boarding schools have a unique culture. 5,000 more boarding schools spread over 68,000 village, is evidence of its own to reveal it as a subculture. The uniqueness of the latter can generate enormous economic value in a professionally managed. ${ }^{16}$

Islamic Boarding schools is one of the oldest Islamic education system in Indonesia and has the important contribution in feeding this nation, especially its role in building the nation in the field of education, religious and moral. ${ }^{17}$ The students came to learn and deepen their studies about Islam, having felt they spread their knowledge to the public at large, doing da'wah to all regions of the country. ${ }^{18}$

As the oldest and original educational institutions (indegenous) Mashallah $\neg$ Indonesians Islamic boarding school, showing a traditional education system, which maintains the system, material, methods, evaluation of traditional fixed based on the values and teachings of Islam. ${ }^{19}$ Boarding schools is one form of Islamic educational institutions who have supported the spread of Islam. ${ }^{20}$

\footnotetext{
${ }^{15}$ Selamet Untung, "Rekonstruksi Manajemen Pendidikan Pesantren," Jurnal Forum Tarbiyah 9, no. 2 (2011): 249-60.

${ }^{16} \mathrm{~A}$. Halim, "Menggali Potensi Ekonomi Pondok Pesantren," in Manajemen Pesantren, ed. Pustaka Pesantren (Yogyakarta: LKIS, 2009). 222.

${ }^{17}$ Misdah, "Manajemen Pondok Pesantren: Studi Perbandingan Tiga Pondok Pesantren di Kalimantan Barat," in 2nd International Seminar on Quality and Affordable Education (ISQAE), 2013, 448-54.

${ }_{18}$ Khusnurdilo Masyhud, Manajemen Pondok Pesantren (Jakarta: Diva Pustaka, 2003). 1.

${ }^{19}$ Mukhlis Sholihin, "Modernisasi Pendidikan Pesantren," Jurnal Tadris6, no. 1 (2011): 28-46.

${ }^{20} \mathrm{Gamal}$ Abdul Nasir Zakaria, "Pondok Pesantren: Changes And Its Futures," Journal of Islamic and Arabic Education 2, no. 2 (2010): 45-52.
} 
In contrast to the traditional systems, Islamic boarding schools that develop adult institution combined between the cottage and the Islamic boarding school system provides education and teaching of Islam with the shoved system, or east lumberjack system the strict adherent of Islam provided cabins or is a large Flying Fox in the term Naat education Modern Cottages meet the criteria of non-formal education. It also administers education formyl shaped madrasah and even public schools in various forms and various vocational level according to the needs of each community. ${ }^{21}$

As the institution of Islamic boarding schools, most of which can be divided into two: traditional Islamic boarding school (salafi) and a modern Islamic boarding school (khalafi). Are conservative salafi Islamic boarding school, while the adaptive nature khalafi Islamic boarding school. Adaptations made to the changes and development of education which is the result of the demands of the development of science and technology. ${ }^{22}$

- Traditional Islamic Boarding Schools

Islamic boarding schools still retains its original form with merely teach the book which are written by scholars of the 20th century 15 using the Arabic language. Teaching patterns by applying a system of "halaqoh" which is held in the mosque or surau. The nature of the teaching system of the halaqoh is memorizing the endpoints in terms of methodology tends to create students who accept and have the science.

This means that science did not develop in the direction of plenary the science of it, but only limited to what is given by the teacher of Islam. The curriculum depends entirely upon the teacher caretakers cottage. There are Islamic boarding school 1976). 162.

${ }^{21}$ Syarif, et al., Kapita Selekta Pondok Pesantren (Jakarta: Paryu Barkah,

${ }^{22}$ Qomar Mujamil, Manajemen Pendiidikan Islam Strategi Baru Pengelolaan Lembaga Pendidikan Islam (Malang: Erlangga, 2010). 58. 
who settled in the cabin (santri mukim), and students who do not realize in the cabin (santri kalong). ${ }^{23}$

- Modern Islamic Boarding Schools

This is the development of Islamic boarding schools, the boarding type due to the orientation of education tend to adopt a system-wide study in classical and traditional study leave the system. The application of modern learning systems is especially apparent on the use of learning classes in the form of a madrasa or school. The curriculum is the curriculum used for authorized school or madrassa that apply nationally. There are Islamic boarding school who settled there scattered around the village. ${ }^{24}$

Position of the Islamic teacher as Coordinator for implementing the process of teaching and learning. In its development, the islamic boarding schools do an innovation in the development of educational system. Thus, Islam is increasingly spread out, thus it can be said that the Islamic institution boarding school is the arrow spread of Islam. ${ }^{25}$

The difference with modern Islamic boarding boarding can be identified from the perspective of its management. Modern Islamic boarding school has been systematically organised and managed to follow the norms of the common management. Meanwhile, the traditional Islamic boarding school walks naturally without attempting to manage effectively. ${ }^{26}$

In Islamic boarding school, is the element that most Islamic teacher essential from boarding school. Development of a Islamic boarding school depends entirely upon the personal capabilities

\footnotetext{
${ }^{23}$ Ghazali, Pendidikan Pesantren Berwawasan Lingkungan. 14.

${ }^{24} \mathrm{M}$. Ali, et al., Kapita Selekta Pendidikan Agama Islam. 94.

${ }^{25} \mathrm{bid}$.

${ }^{26}$ Mujamil, Manajemen Pendiidikan Islam Strategi Baru Pengelolaan Lembaga Pendidikan Islam. 58.
} 
of the islamic teacher. ${ }^{27} \mathrm{Kyai}$ is the forerunner and the staple element of an Islamic boarding school. Islamic boarding schools apply the principle of tasamuh (tolerant), tawasuth wal i'tidal (simple), tawazun (full consideration), and ukhuwah (fraternity). ${ }^{28}$

Kyai is not only categorized as a religious elite, but also as an elite of Islamic boarding school, which has a high authority in storing and spreading of religious knowledge as well as a pattern of coloring and shape competent leadership which is in boarding school. The charismatic type attached to himself become a benchmark boarding authority. ${ }^{29}$

Among the institutions that develop, Islamic boarding schools have strong characteristics in order of formation of the students (School). It is empirically proven in several Islamic boarding schools. ${ }^{30}$ The success of the character education at the Islamic boarding school was influenced by the example and real examples in life context and in the activities of learning. ${ }^{31}$

The Establishment of Darussalam Gontor Modern Islamic Institution

Historically, Darussalam Gontor Modern Islamic Institution is derived from the traditional Islamic boarding schools located in Tegalsari $10 \mathrm{KM}$ South of the town of Ponorogo or $3 \mathrm{KM}$ West of Gontor now. The lodge was founded by Kiyai Ageng Muhammad

${ }^{27}$ Zamakhsari Dhofier, Tradisi Pesantren: Studi Tentang Pandangan Hidup Kyai (Jakarta: LP3ES, 1992). 61.

${ }^{28}$ Syawaludin, Peranan Pengasuh Pondok Pesantren Dalam Mengembangkan Budaya Damai di Provinsi Gorontalo (Jakarta: Kementrian Agama RI Badan Litbang dan Diklat Puslitbang Kehidupan Keagamaan, 2010). 132.

${ }^{29}$ Sukamto, Kepemimpinan Kiyai Dalam Pesantren (Jakarta: Pustaka LP3ES, 1999). 13.

${ }^{30}$ Uci Sanusi, "Pendidikan Kemandirian Di Pondok Pesantren," Jurnal Pendidikan Agama Islam- Ta'lim 10, no. 2 (2012): 123-39.

${ }^{31}$ Kamin Sumardi, "Potret Pendidikan Karakter Di Pondok Pesantren Salafiah," Jurnal Pendidikan Karakter 2, no. 3 (2012): 280-92. 
besari in the 18th century and reached its peak when led by Kyai Hasan Anom Besari (1800-1862). ${ }^{32}$

Darussalam Gontor Modern Islamic Institution has many good achievements in carving out local and national scale. Pioneered by Kiai RM Hadikusumo Sulaiman Jamal and his son Kiai Archam Anom Besari, awarded to spread to all corners of the ground water with a wide range of professions. RM. Hadikusumo is the grandson of Prince Hadiraja Duke kanjeng Anom from Sultanate of Cirebon Kasepuhan, West Java. ${ }^{33}$

In the following period, began to erode, and when the Islamic boarding school was led by Kyai Santoso Besari Anom and the Islamic boarding school live a little and his teaching just centred on a small mosque located in front of the home of kyai. Kyai santoso died, traditional Gontor Islamic boarding school that was built by Kyai Sulaiman Jamal is really gone. ${ }^{34}$

There is no clear documentation about when the first generation of Gontor collapse. However, from a variety of the utterance is submitted that among the causes of the downfall is the lack of anticipation towards the preparation of competent cadres who will continue the struggle for Maisonette in the future. ${ }^{35}$

After Kyai Santoso, mother Mrs still sought to carry on her husband's struggle with his son, three people named Ahmad Sahal (fifth), Zaenuddin Fannani (sixth) and Imam Zarkasyi (the youngest) were sent to Islamic boarding schools of the salaf and

\footnotetext{
${ }^{32} J$ uhaya S. Praja and Mukhlisin Muzarie, Pranata Ekonomi Islam: Wakaf (Jawa Barat: STAIC Press, 2009). 176.

${ }^{33}$ Direktorat Pendidikan Diniyah dan Pondok Pesantren, Direktori Pesantren (Jakarta: Departemen Agama Republik Indonesia, 2007). 204.

${ }^{34}$ Praja and Mukhlisin Muzarie, Pranata Ekonomi Islam: Wakaf. 176.

${ }^{35}$ Mardiyah, Kepemimpinan Kiyai Dalam Memelihara Budaya Organisasi (Malang: Additya Media Publishing, 2012). 127.
} 
the modern with the hope of someday reviving Gontor encompasses that has dissipated. ${ }^{36}$

The resurrection of the Darussalam into a modern Islamic boarding schools initiated by KH. Ahmad Sahal, 12 Will Early 1345 $\mathrm{H}$ or 9 October $1926 \mathrm{~m}$. KH Ahmad Sahal is the older brother of $\mathrm{KH}$. Zainuddin Fanani and KH. Zarkasyi Priest. When the Central boarding school initiated to modernize itself. Priest Zarkasyi studying Solo (1925) and proceed to the Normal School of Islam, the leadership of Mahmud Yunus in Padang, West Sumatra. ${ }^{37}$

While Zainuddin Fanani became School Opzsier in Bengkulen. They learn to kyai was with great diligence and sincerity; use the knowledge that has been gained and for its community circles to each. ${ }^{38}$

The first step is done Kyai Ahmad Sahal to improve conditions for these communities is nurture and educate children of the village with educational activities Tarbiyatul Athfal (education of children) (1926). The existence of these educational activities, the people from outside the village starts Gontor flock to. Because of the many enthusiasts, Tarbiyatul Athfal Gontor opening several branches in villages around the Gontor then given name was Tarbiyatul Islam (Islamic education). ${ }^{39}$

At the time Tarbiyatul Athfal goes 7 years, Ahmad Sahal opened madrassa advanced level named "Sullamul Mutaallimin" education under 3 years old, to accommodate the interest of students who wish to continue their education to a higher level.. ${ }^{40}$

\footnotetext{
${ }^{36}$ Praja and Mukhlisin Muzarie, Pranata Ekonomi Islam: Wakaf. 177.

${ }^{37}$ Pondok Modern Gontor:, Sejarah Balai Pendidikan Pondok Modern Gontor Indonesia Dari Zaman Wali Ke Zaman Tegalsari (Ponorogo: Gontor Press, 1997). 12.

${ }^{38}$ lbid..

${ }^{39}$ Pondok Modern Gontor:, Biografi K.H. Imam Zarkasyi: Dari Gontor Merintis Pesantren Modern (Ponorogo: Gontor Press, 1996). 43.

${ }^{40}$ Praja and Mukhlisin Muzarie, Pranata Ekonomi Islam: Wakaf. 177.
} 
The arrival of the highly awaited Zarkasyi K.H. Priest by his brother, because he will bring these new programs. Approximately for eleven years, from 1925 until 1936, K.H. Priest Zarkasyi spent her years out of home town to study. Upon arrival at Gontor, K.H. Priest Zarkasyi directly develop new Gontor started by his older brother. ${ }^{41}$

The struggle carried out By Priest Zarkasyi by offering alternative education that integrates the two systems, i.e. formal education education with tiered cottage. More in 1940, founded the High Priest Zarkasyi Islamic boarding school (Ma'had Aly). ${ }^{42}$ Meanwhile, Kyai Fanani Zainuddin who is still at Islamic School Opzsier schools in Bengkulen, any anticipated his return because his ideas as one of the founders of Darussalam Gontor is indispensable. ${ }^{43}$

The most major of Darussalam Gontor is to prepare competent cadres for the people of Islam in Indonesia, by combining these advantages the educational system of ancient with modern education theory and practice. Various models of the educational institutions have affects Gontor, they call AlAzhar, Aligarh, Shantiniketan, and Syanghit. ${ }^{44}$

Darussalam Gontor Modern Islamic Institution is one that is very instrumental in Indonesia education coloring even Southeast Asia. The whole potential and capability to realize the Mission of shed. It is increasingly in control with no involvement of the Darussalam Gontor practical politics, and in no way affiliated to any community organizations, so that they can independently

\footnotetext{
Modern. 42.

${ }^{42}$ Praja and Mukhlisin Muzarie, Pranata Ekonomi Islam: Wakaf. 177. Modern. 41.

${ }^{43}$ Gontor:, Biografi K.H. Imam Zarkasyi: Dari Gontor Merintis Pesantren

${ }^{44}$ Lance Castles, Gontor Sebuah Catatan Lama (Ponorogo: Trimurti Gontor, 1991). 3.
}

${ }^{41}$ Gontor:, Biografi K.H. Imam Zarkasyi: Dari Gontor Merintis Pesantren 
determine the pace and have a wider space in the field of education and teaching. ${ }^{45}$

\section{Gontor Philosophical Education ${ }^{46}$}

- The Vision of Darussalam Gontor Modern Islamic Institution

As an educational institution cadre leader, cadres of printer people; became a place of worship thalab al-ilmi and became a center of Islamic knowledge, the language of the Qur'an, and General Science, keeping boarding-at-heart

- The Missions of Darussalam Gontor Modern Islamic Institution

a. To prepare a generation of superior quality and leading to the formation of khairu ummah.

b. To educate and develop next-generation mukmun-muslim able-bodied high, virtuous, knowledgeable, and freethinking, as well as serving to the community

c. Teaching the science of religion and the public in a balanced way towards the formation of the scholars intellect

d. To prepare the citizens of faith and piety to Allah SWT

- The Mottoes of Darussalam Gontor Modern Islamic Institution

a. Noble Character. Virtuous or moral education main runway is karimah to the whole Islamic boarding school, realization of planting this motto is done through all the elements of education.

${ }^{45}$ Ahmad Suharto, Profil Pondok Modern Darussalam Gontor (Ponorogo: Darussalam Press, 2011). 1.

${ }^{46}$ Data adopted from "Warta Dunia Pondok Modern Darussalam Gontor Vol. 69," Darussalam Press, 2015. i 
b. Sound Body. The establishment and maintenance of a healthy body at stake in education in Modern Cottages. Therefore the students can carry out the tasks of living, learning and worship with their best

c. Broad Knowledge. The students were educated in systemically to have intellectual independence, are able to expand their knowledge and insights. Students not only science, but also taught how to learn as well as provided with the keys that can be used to unlock the storehouse of knowledge.

d. Independent Mind. Independent mind must remain free, value-based, active and positive, free of charge and remains in the frame of laws and norms. This motto is embedded after the student has high, able-bodied, and well rounded. ${ }^{47}$

- The Five Spirits of Darussalam Gontor Modern Islamic Institution

The spirits are values that must be imbued by anyone who's been in Gontor. Not only students, but also applies to teachers, kyai, even the family of kyai. These include soul-senses the sincerity, simplicity, Ukhuwah Islamiyah, Autonomy, and freedom. The whole of life in the Modern Cottage Gontor grounded and imbued by Islamic values which can be summed up in Five spirits as follows:

a. Sincerity. This means the soul of the selfless, i.e. do something not because it is driven by the desire for profit. The deeds done with intention is solely to worship iillah. $^{48}$ This includes all the atmosphere of life in Islamic boarding schools. In the Islamic boarding schools no one who have

${ }^{47}$ Suharto, Profil Pondok Modern Darussalam Gontor. 10.

${ }^{48} \mathrm{Ibid} .7$. 
intend or desire to acquire in Exchange for services in the form of the material.

b. Simplicity. Simple means reasonable, according to needs, not passive or wants, there are also poor and destitute. Thus in the soul of simplicity that there are values of strength, ability, patience, and self-control in the face of life's struggles. ${ }^{49}$

c. Self-Sufficiency. Self-help is capable of powerful weapons which included boarding school to its Islamic boarding school. Not only means that the student is able to learn and practice take care of everything himself, but Islamic boarding schools are also able to achieve so that never trust his life to help others. ${ }^{50}$

d. Islamic Brotherhood. Life in Islamic boarding schools should be covered by the atmosphere of fraternity that is familiar, thus it is all love and grief felt ukhuwah braided together in the (brotherhood) diniyyah not only for Islamic boarding schools in itself, but it also affects the people in unity towards the society upon returning from the cottage. ${ }^{51}$

e. Freedom. In determining the future, choose a land struggle, choose field: livelihood as farmers, merchants, military officers, and a variety of other professions, for the benefit and keep carrying out the Mission of the struggle as a da' $i$ in society. ${ }^{52}$ These freedoms should be restored in the lines of positive discipline, with full responsibility,

${ }^{49}$ Imam Zarkasyi, "Diktat Public Lecture Introduction Week Darussal am Modern Gontor Islamic Institution, with Some Minor Improvements and Additions From Year to Year, Since 1939," n.d. 12.

${ }^{50}$ Suharto, Profil Pondok Modern Darussalam Gontor. 8.

${ }^{51}$ Zarkasyi, "Diktat Public Lecture Introduction Week Darussalam Modern Gontor Islamic Institution, with Some Minor Improvements and Additions From Year to Year, Since 1939." 13.

${ }^{52}$ Suharto, Profil Pondok Modern Darussalam Gontor. 8. 
both in the life of Islamic boarding schools and in the community.

- The Long-Term Plan of Darussalam Gontor Modern Islamic Institution

This long-term plan is standard to manage this institution, standard to undertake the school activities and standard to direct the advancement of Darussalam Gontor Modern Integrated Islamic Instituion. Here is its detailed description. ${ }^{53}$

a. Education and Instruction. The main content of this longterm plans is to maintain the system, and improve its quality which have been articulated by the founding fathers that. Kulliyah al-Mu'allimīn al-Islāmiyyah (The Islamic Teachers Training College) is the final system for high school level of education. Meanwhile, the University of Darussalam is the ideal form at the level of postgraduate education system. Both these two education institution must be equipped by integrated by integrated dormitory, a campus to actualize extraculicular activities to construct the character, and life skill as well, which annually, these two institutions improved step by step.

b. Cadre Building. This institutional program is one of the important plans which have been undertaken regularly by Gontor Modern Integrated Islamic Institution. This longterm plan is actualized by improving the cadre's quality and quantity as well. The medium of improvement is through high learning, doing assignment, taking vocation, and rolling places for the institutional services. Through this approaches the cadres may achieve their maturity and ready to take a stick of management from the previous leaders.

\section{Vol.69." i}

${ }^{53}$ Data adopted from: “Warta Dunia Pondok Modern Darussalam Gontor 
c. Building: the Facilities of Education. The activity of building construction on the other hand, is continuously carried out in various forms to avail the adequate school facilities for the whole students. The spirit of this construction is the real articulation from the late H. Imam Zarkasyi, the founding father of Gontor.

d. Chizanatullah (Funding Resources). The spirit of self-help of Darussalam Gontor is not only at the education system, but also actualized at the funding resources. This school program is carried out to further assist the activities of teaching and learning independently. The reality of this program is in the form of the establishment of economic enterprises which at the time being amount to 30 units approximately, include: agriculture, field, trade, and industrial services, at the central campus and its brances as well. ${ }^{54}$

e. Family Welfare. The family welfare, on the other hand, is actualized through provision of basic facilities, such as: housing, basic meals and logistic, clothes, pilgrimage and umrah opportunity, tour with the family, and general checked up to maintain the health.

Darussalam Gontor Modern Islamic Institution Transformation Toward The Modernity

\section{Based on Total Quality Control}

Vision and mission became the cornerstone of the Foundation of all activities. The mottoes became guidelines in achieving an objective. The Long-Term Plan becomes spirit in carrying out all activities. As well, Five-term into a program that provides direction and guidance for realizing development efforts and progress. The entire value and spirit of the cottage became a

\footnotetext{
${ }^{54}$ Data adopted from: I bid.
} 
unified whole (all in one system) so that the creation of the overall success. ${ }^{55}$

The philosophical foundation of the cultivation of the values and spirit, the lodge became the main factor in the success of the lodge. Philosophical in the struggle and fight for, moving and moving, worship talabu 'ilmi khair ummah, towards the powerful with the energy in performing all activities. Each staff/asatidz who manages the lodge feel such a huge responsibility in developing the activity of the lodge. ${ }^{56}$

In all its activities, Darussalam Gontor Modern Institution formed several institutions (organizational structure) to the creation of total quality control. Different case with the organizational structure of the traditional boarding schools the supreme power is held by the kyai as founder of the lodge. However, it is not the case with Modern Cottages Darussalam Gontor. Supreme power is held by an agency called body of Waqf.

To perform its functions, the Agency formed a Waqf institutions and appointed Chairman of the agency that is in charge to run vision cabin. The Supreme executive agency is the leader of the lodge, underneath the upbringing of Students, the maintenance and expansion of the Foundation's Endowments Modern Gontor (YPPWPM), Kulliyatul Mua'llimin Al-Islamiyah (KMI), University of Darussalam Gontor, and Family ties the Modern Cottage Darussalam Gontor (IKPM), as well as the leadership of the lodge branch. ${ }^{57}$

\footnotetext{
${ }^{55}$ Data adopted from Interview with Guidence and Concelling Department of Darussalam Modern Islamic Institution.

${ }^{56}$ Muhammad Iqbal Fasa, "Manajemen Unit Usaha Pesantren" (UIN Sunan Kalijaga Yogyakarta, 2015). 136.

${ }^{57}$ Data adopted from interview with The Foundation for The Maintenance and Expansion of The Endowments of the Modern Gontor Department.
} 
Organization Structure

Darussalam Gontor Modern Islamic Institution

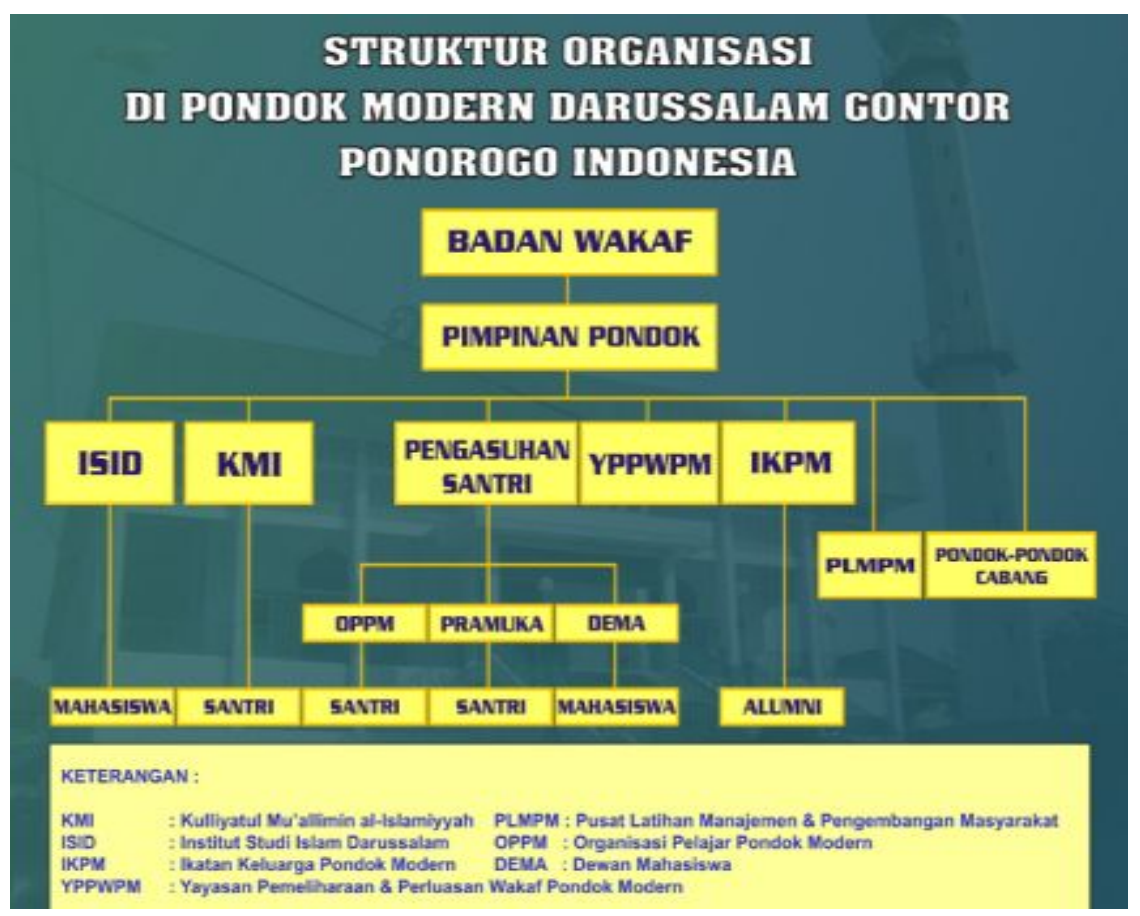

a. Guidence and Concelling Department ${ }^{58}$

The agency that administered directly by the leadership of the Lodge serves as the central traffic instructional and consulting organizations each activity students and teachers; Student Council and student organizations of Darussalam Gontor. The role and functions of the other institutions is as the spearhead of the whole construction of the totality of the activities of the students. Total Quality Control is the process of integration or unification of the vision and mission as well as the implementation of the related planning, organizing, leadership and control.

${ }^{58}$ Data adopted from interview with Guidence and Concelling Department of Darussalam Modern Islamic Institution. 
The control and assigning dates from a meeting that gave rise to the program, then the program is implemented, the existence of a violation, then the presence of controling as a whole. Thus, the creation of total quality control in carrying out the implementation of a management business unit at Gontor Islamic school.

Total Quality Control is carried out in implementing the totality of the activities of the lodge. With the briefing form systems and patterns. As well as the continued assignment of covering the Division of tasks, the programme of work and the identification of problems. Then the existence of a coaching approach to value programs, motivation, work ethic, and ubudiyah. And evaluation in terms of performance, quality of work, effectiveness (results) and efficiency (process).

With the Agency endowments, all assets maintained good profit obtained will be used for the benefit of boarding school. So, total quality control will be well underway. Controlling the key in the whole management. With the evaluation, there will be an impact from there. Will appear 2 results, i.e. positive and negative results. A positive result can be extended to the next level, whereas negative results can be evaluated over the performance is done.

Total Quality Control is intended to identify the existing problems, then complete the constraints, continued looking for inspiration in the process activity with fostering a sense of responsibility, as well as creating life as desired or directed.

b. Kulliyatul Mu'allimin Islamiyah (KMI) ${ }^{59}$

Kulliyatul Islamiyah Mu'allimin (KMI) is the agency that are responsible of the continuity of education and teaching in the Modern Cottage Darussalam Gontor. There are seven sections that

\footnotetext{
${ }^{59}$ Data adopted from interview with Kulliyatul Islamiyah Mu'allimin (KMI) Department of Darussalam Modern Islamic Institution.
} 
help work Director, which is part of the process of teaching and learning, Career Coaching Part teacher, Part of research and curriculum development, and infrastructure Section, part library, Part of the laboratory, and Administrative Sections. ${ }^{60}$

Frame of Total Quality Control

Darussalam Modern Gontor Islamic Institution ${ }^{61}$

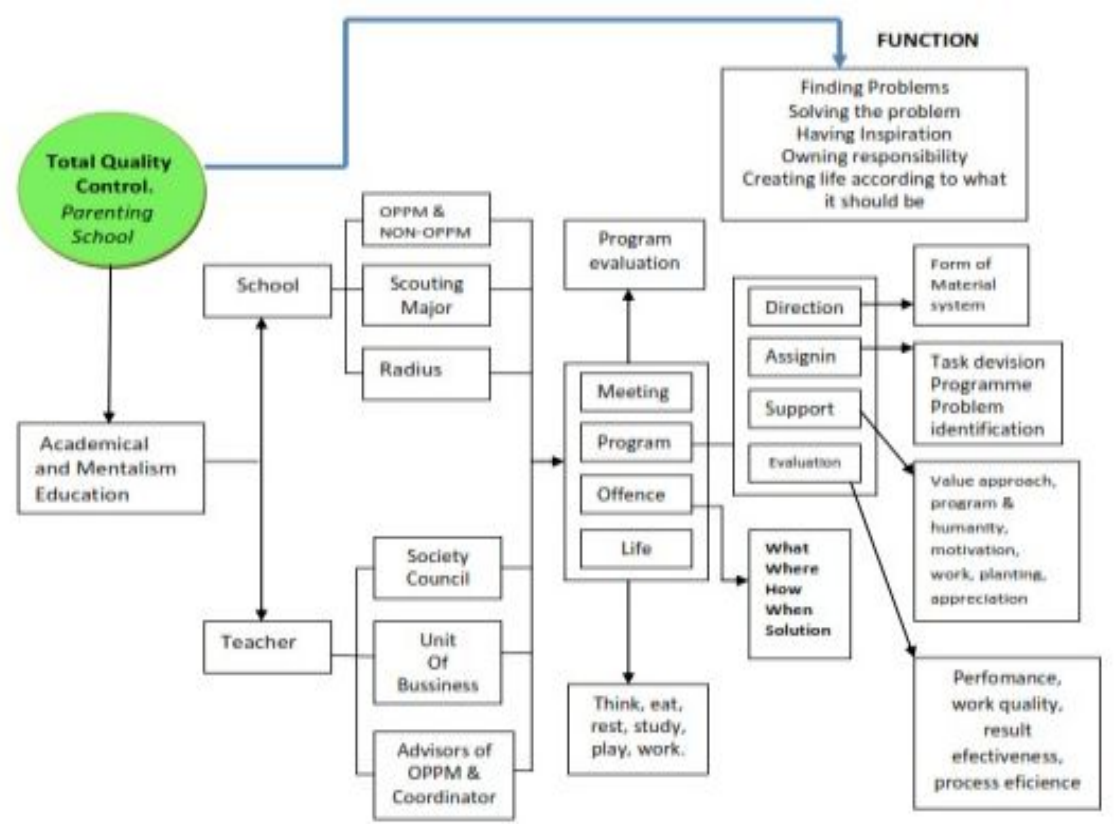

C. University of Darussalam (UNIDA) ${ }^{62}$

University of Darussalam (UNIDA) is the first institution of higher education in Indonesia that aligning the patterns of remembrance, thought, and sports in every small breath that

${ }^{60}$ Data adopted from interview with Kulliyatul Islamiyah Mu'allimin (KMI) Department of Darussalam Modern Islamic Institution.

${ }^{61}$ Data adopted from interview with Guidence and Concelling Department of Darussalam Modern Islamic Institution. 69." 8.

${ }^{62}$ Adopted from "Warta Dunia Pondok Modern Darussalam Gontor Vol. 
keeps first settled and stepping forward with cling to atmospheric values kepesantrenan. UNIDA has become the center of the development of Islamic sciences and common Center language and civilization.

In General, the UNIDA excellence lies in the all in one campus system or integrated system. The design of teaching and learning are created inside and outside the College. Dormitory, Mosque, library, Lecture Hall, laboratories, development languages, sports, the arts, and student organization of interlinked between one another with carrying out the education for the students for 24 hours.

d. Modern Gontor Family Assosiation (IKPM) ${ }^{63}$

Modern Gontor Family Assosiation (IKPM) is an institution moving weaves between hospitality members, as well as move the alumni to benefit the Muslims in favor of a Modern Cottage syiar Darussalam Gontor to society.

Modern Gontor Family Assosiation (IKPM) spread across parts of Indonesia, a nation of Nusantra even spread widely to some countries such as Malaysia, Qatar, Brunei Darussalam, and others. The existence of family ties the Modern Cottage, alumni can coordinate between one another, despite already being the alumni cottage.

e. The Foundation for the maintenance and expansion of the Endowments of the Modern Cottage (YPPWPM) ${ }^{.64}$

For the sake of passage of all activities as well as the mobilization of the economy which is in the Darussalam Gontor, the maintenance and expansion of the Foundation's Endowments of Modern Cottage (Y PPWPM) is the Institute responsible with it.

\footnotetext{
${ }^{63} \mathrm{bid} .18$.

${ }^{64}$ Data adopted from interview with The Foundation for The Maintenance and Expansion of The Endowments of the Modern Gontor Department.
} 
YPPWPM forming some divisions for the sake of the establishment of smooth coordination among one another. Implementing the activities carried out by the agricultural part, Secretary, Treasurer, plantation, cooperative of Islamic boarding school, vehicles, investaris.

Cooperative boarding schools is the most important implementing agency in the development of the wheel of the economy of the business unit that exists in a Modern Cottage Darussalam Gontor.

\section{Based on Cadre Recruitment}

Cadre recruitment becomes very important for the survival of the institution, the history gives a lesson that many Islamic boarding school die because the process of cadre recruitment is very weak. Thus, the existence of a cadre of Islamic boarding school within its teacher (Trine) died, did not enter the dead, because there is nothing to pass on, and so does the incoherence of that desired. ${ }^{65}$

Darussalam Gontor Modern Islamic Institution put cadre recruitment as a superstructure on the leadership succession. The cadre recruitment steps include: Uswah hasanah, direction, approach, motivation, assignment, evaluation, construction of the inner given birth perjenjangan.

Cadre recruitment process begins from the moment students enter a Modern Cottage start class I to class VI. When students are at the level of the student cadre recruitment process end, increasingly selective. Because the whole resident students will also hold a final mandate in the Modern Cottage student organizations (OPPM). From these organizations, skill and expertise were formed both in terms of the management of the business unit, scouting, and self-improvement.

${ }^{65}$ Data adopted from interview with Guidence and Concelling Department of Darussalam Modern Islamic Institution. 
After the end of the learning process of the student's end, then the process of cadre recruitment more selective. That is because the whole Rasta will spread to the rest of Indonesia. Best of the best students will be placed in the Modern Cottage Darussalam Gontor 1. With the expertise of the previous class VI, Division placement assignments could be made the cornerstone of ustadz appropriate expertise field of each individual. ${ }^{66}$

Cadre recruitment process continues until the ustadz first year and beyond. When the period of service under the first year, the asatidz placed appropriate on areas of expertise themselves when students finish. Although there are divisions that do not fit with expertise, process assignments will be done with practice practice by learning, i.e. education directly.

In the management of each business unit, the asatidz will be built and directed by the asatidz and senior representatives from the Foundation. With the process of mentoring, the asatidz began his new assignment can perform to its full potential.

When stepping on the second year, there is usually some ustadz finished carrying out the mandate of devotion. Because of the mandatory programs serve only 1 year. As a result, turnaround assignments will occur. However, each business unit have a cadre who settled from the business units, although only 1 person. With the expertise and experience that has been owned, ustadz senior has obligations in providing knowledge and experience of the management of the business unit to the whole asatidz.

Cadre recruitment process will spin onwards as expressed before. That, ustadz junior will be trained by Ustad more senior, ustadz senior will be built and directed by a representative of the Foundation of the lodge. Representatives of the Foundation's cooperative cottages will get referrals from the direction of the

\footnotetext{
${ }^{66}$ Data adopted from interview with Guidence and Concelling Department of Darussalam Modern Islamic Institution.
} 
cottage. The leadership of the hut will get referrals from the Endowments. ${ }^{67}$

\section{Based on Teaching 24 Hours}

The nature of boarding schools located in content/ his soul, not on her skin. Contents of boarding schools is education. For several centuries the boarding schools have been providing education (rohaniyah), which is very valuable to the students as competent cadres muballigh and leader of the people in a variety of life. Education carried out by Modern Cottages Darussalam Gontor impose 24-hour instruction divided into daily and weekly activities:

Daily Activity of Darussalam Modern Gontor Islamic Institution ${ }^{68}$

\begin{tabular}{ccl}
\hline No. & \multicolumn{1}{c}{ TIME } & \multicolumn{1}{c}{ ACTIVITY } \\
\hline 1 & $04.00-05.30$ & $\begin{array}{l}\text { 1. Waking up } \\
\text { 2. Shalat Dawn (Pray in the morning) } \\
\text { 3. Guidance toward the ability of Arabic and English } \\
\text { 4. Reading Holy Al-Qur'an }\end{array}$ \\
\hline 2 & $05.30-06.00$ & $\begin{array}{l}\text { 1. Physical exercise } \\
\text { 2. Taking a bath } \\
\text { 3. Language courses, Literature, Skills, etc. }\end{array}$ \\
\hline 3 & $06.00-06.45$ & $\begin{array}{l}\text { 1. Breakfast } \\
\text { 2. Preparation for entering the class }\end{array}$ \\
\hline 4 & $07.00-12.50$ & Morning Class \\
\hline 5 & $12.50-13.00$ & Out of the class \\
\hline 6 & $13.00-14.00$ & $\begin{array}{l}\text { 1. Shalat Zuhur (Pray with the community) } \\
\text { 2. Lunch }\end{array}$ \\
\hline 7 & $14.00-15.00$ & Starting evening class \\
\hline 8 & $15.00-15.45$ & $\begin{array}{l}\text { 1. Shalat Ashar (Pray together) } \\
\text { 2. Reading Holy Al-Qur'an }\end{array}$ \\
\hline
\end{tabular}

${ }^{67}$ Data adopted from interview with The Foundation for The Maintenance and Expansion of The Endowments of the Modern Gontor Department.

${ }^{68}$ Data adopted from interview with Guidence and Concelling Department of Darussalam Modern Islamic Institution. 


\begin{tabular}{|c|c|c|}
\hline No. & TIME & ACTIVITY \\
\hline 9 & $15.45-16.45$ & Free activity \\
\hline 10 & $16.45-17.15$ & Taking bath and be ready to Mosqiu to have pray. \\
\hline 11 & $17.15-18.30$ & $\begin{array}{l}\text { 1. Shalat Maghrib (Pray as one) } \\
\text { 2. Reading Holy Al-Qur'an }\end{array}$ \\
\hline 12 & $18.30-19.30$ & Dinner \\
\hline 13 & $19.30-20.00$ & Shalat Isya berjamaah (Having night pray) \\
\hline 14 & $20.00-22.00$ & Studying together in each class \\
\hline 15 & $22.00-04.00$ & $\begin{array}{l}\text { Night rest (The car etaker of boarding school secure the } \\
\text { night) }\end{array}$ \\
\hline \multicolumn{3}{|c|}{$\begin{array}{l}\text { Weekly Activity of Darussalam Modern Gontor Islamic } \\
\text { Institution }\end{array}$} \\
\hline NO & DAYS & ACTIVITIES \\
\hline 1 & Saturday & There is no change from the daily schedule \\
\hline 2 & Sunnday & $\begin{array}{l}\text { Early in the day as the daily schedule, evenings after } \\
\text { Ishaa pilgrims practice speeches (muhadharah) in the } \\
\text { language of the English for classes I-IV, class V and class } \\
\text { VI, the discussion became supervisor for group exercises } \\
\text { speech. }\end{array}$ \\
\hline 3 & Monday & There is no change from the daily schedule. \\
\hline 4 & Tuesday & $\begin{array}{l}\text { Morning, after worshipers praying, } \\
\text { conversational Arabic/ English, } \\
\text { morning mandatory for the students. }\end{array}$ \\
\hline 5 & Wednesday & There is no change from the daily schedule. \\
\hline 6 & Thursday & $\begin{array}{l}\text { The last two hours of lessons in the morning used to } \\
\text { practice speech in Arabic. Noon, } 13.45-16.00 \text {, exercise of } \\
\text { Scouting. Night, 20.00-21.30, muhadharah Indonesian } \\
\text { language }\end{array}$ \\
\hline 7 & Friday & $\begin{array}{l}\text { The morning activities of the conversations in } \\
\text { Arabic/ English proceed with the compulsory morning } \\
\text { run. After that the work program of cleaning up the } \\
\text { environment of the campus. Next }\end{array}$ \\
\hline
\end{tabular}

${ }^{69}$ Data adopted from interview with Guidence and Concelling Department of Dar ussalam Modern Islamic Institution. 
Supporting research conducted by Sugiharti, that, to make the Islamic boarding school as a center of muslim civilization in Indonesia, Generally it needs a better strategy (Grand Strategy) which includes: ${ }^{70}$

- Understands the concept of the resurrection and Foundation;

- Formulate back boarding purposes;

- Fix the pesantren education system;

- Improving the management of boarding school;

- Increase the competencies of the output of the boarding school;

- Refungsionalisasi boarding school;

- Establish a cooperation partner to the outside;

- Increase the role Islamic boarding school;

- Modernization in technology, information and communication;

- The flagship Program in the era of globalization.

Darussalam Modern Gontor Islamic Institution is growing so rapidly. Here is the development of Darussalam Modern Gontor Islamic Institution in Indonesia.

${ }^{70}$ Diyah Yuli Sugiharti, "Strategi Pengembangan Pondok Pesantren Dalam Membangun Peradaban Muslim Di Indonesia," Jurnal Edukasi 3, no. 1 (2011): 8-37. 
Vol. 14, No. 1, Juni 2017: 141-174

Recapitulation of Students and Teachers

Darussalam Modern Gontor Islamic Institution . ${ }^{71}$

\begin{tabular}{|c|c|c|c|}
\hline No. & $\begin{array}{l}\text { Pondok Modern } \\
\text { Darussalam }\end{array}$ & Location & Amount \\
\hline 1 & Gontor 1 & Gontor Ponorogo & 4.498 \\
\hline 2 & Gontor 2 & Madusari Ponorogo & 1.385 \\
\hline 3 & Gontor 3 & Nggu urah Kediri & 1.595 \\
\hline 4 & Gontor For Girl 1 & Mantingan Ngawi & 3.930 \\
\hline 5 & Gontor For Girl 2 & Mantingan Ngawi & 1.184 \\
\hline 6 & Gontor For Girl 3 & Karangbanyu Ngawi & 2.805 \\
\hline 7 & Gontor For Girl 4 & Kendari Sul Tenggara & 325 \\
\hline 8 & Gontor For Girl 5 & Kandangan Kediri & 1.352 \\
\hline 9 & Gontor For Girl 6 & Poso Sulawesi Tengah & 144 \\
\hline 10 & Gontor For Girl 7 & Pekan Baru Riau & 893 \\
\hline 11 & Gontor 5 & Kaliagung Banyuwangi & 1.279 \\
\hline 12 & Gontor 6 & Magelang Jawa Tengah & 1.315 \\
\hline 13 & Gontor 7 & Kendari Sul Tenggara & 353 \\
\hline 14 & Gontor 8 & Way Jepara Lampung & 21 \\
\hline 15 & Gontor 9 & Kalianda Lampung & 635 \\
\hline 16 & Gontor 10 & Darul Amin Aceh & 141 \\
\hline 17 & Gontor 11 & Sulit Air Padang & 69 \\
\hline 18 & Gontor 12 & $\begin{array}{l}\text { Tanjung Jabung Timur } \\
\text { Jambi }\end{array}$ & 380 \\
\hline 19 & Gontor 13 & Poso Sulawesi Tengah & 190 \\
\hline 20 & Gontor 14 & Siak, Riau & 178 \\
\hline 21 & $\begin{array}{l}\text { University of Darussalam } \\
\text { Gontor }\end{array}$ & Siman & 1.073 \\
\hline \multirow[t]{2}{*}{22} & MBUD & Mantingan & 108 \\
\hline & TOTAL & & 23.853 \\
\hline
\end{tabular}

${ }^{71}$ Data adopted from Secretary Department of Darussalam Modern Gontor Islamic Institution 18 April 2017. 


\section{Conclusions}

Darussalam Gontor Modern Islamic Boarding School is one that is very instrumental in Indonesia education coloring even Southeast Asia. The whole potential and capability to realize the Mission of shed. It is increasingly in control with no involvement of the Modern Cottage Darussalam Gontor practical politics, and in no way affiliated to any community organizations, so that they can independently determine the pace and have a wider space in the field of education and teaching.

There are five Philosophical Education of Darussalam Gontor Modern Islamic Institution: First, The Vision: As an educational institution cadre leader, cadres of printer people; became a place of worship thalab al-ilmi and became a center of Islamic knowledge, the language of the Qur'an, and General Science, keeping boarding-at-heart, Second, The Missions: (a) To prepare a generation of superior quality and leading to the formation of khairu ummah (b) To educate and develop nextgeneration mukmun-muslim able-bodied high, virtuous, knowledgeable, and free-thinking, as well as serving to the community (c) Teaching the science of religion and the public in a balanced way towards the formation of the scholars intellect (d) To prepare the citizens of faith and piety to Allah SWT, Third, The Mottoes: (a) Noble Character, (b) Sound Body, (c) Broad Knowledge (d) Independent Mind, Fourth, The Five Spirits: (a) Sincerity, (b) Simplicity (c) Self-Sufficiency (d) Islamic Brotherhood (e) Freedom. Fifth, The Long-Term Plan: (a) Education and Instruction (b) Cadre Building (c) Building: the Facilities of Education (d) Chizanatullah (Funding Resources) (e) Family Welfare.

Darussalam Gontor Modern Islamic Institution Transformation Toward The Modernity Includes several things, First, Based On Total Quality Control: Vision and mission became the cornerstone of the Foundation of all activities. The mottoes 
became guidelines in achieving an objective. The Long-Term Plan becomes spirit in carrying out all activities. As well, Five-term into a program that provides direction and guidance for realizing development efforts and progress. The entire value and spirit of the cottage became a unified whole (all in one system) so that the creation of the overall success.

Second, Based On Cadre Recruitment: Darussalam Gontor Modern Islamic Institution put cadre recruitment as a superstructure on the leadership succession. The cadre recruitment steps include: Uswah hasanah, direction, approach, motivation, assignment, evaluation, construction of the inner given birth step by step. Cadre recruitment process begins from the moment students enter a Modern Cottage start class I to class VI. When students are at the level of the student cadre recruitment process end, increasingly selective. Because the whole resident students will also hold a final mandate in the student organizations (OPPM).

Third, Based on Teaching 24 Hours : The nature of boarding schools located in content/ his soul, not on her skin. Contents of boarding schools is education. For several centuries the boarding schools have been providing education (rohaniyah), which is very valuable to the students as competent cadres muballigh and leader of the people in a variety of life. Education carried out by Darussalam Gontor Modern Islamic Institution impose 24-hour instruction divided into daily and weekly activities.

This study only conducted one case study in depth at Darussalam Gontor Modern Islamic Institution. Further research is expected to conduct research in different objects, as well as comparing in depth from some modern and traditional Islamic boarding school which can then be drawn a characteristic of pesantren which can be improve the quality of pesantren education in Indonesia. 
Muhammad Iqbal Fasa, Gontor as the Learning...

\section{References}

Abdul Mu'in. Pengembangan Ekonomi Pondok Pesantren. Jakarta: Prasasti IKAPI, 2007.

Castles, Lance. Gontor Sebuah Catatan Lama. Ponorogo: Trimurti Gontor, 1991.

Dhofier, Zamakhsari. Tradisi Pesantren: Studi Tentang Pandangan Hidup Kyai. Jakarta: LP3ES, 1992.

Direktorat Pendidikan Diniyah dan Pondok Pesantren. Direktori Pesantren. Jakarta: Departemen Agama Republik Indonesia, 2007.

Fasa, Muhammad Iqbal. "Manajemen Unit Usaha Pesantren." UIN Sunan Kalijaga Yogyakarta, 2015.

Gardono, Iwan. Pesantren Dan Demokrasi Jejak Demokrasi Dalam Islam. Jakarta: Titian Pena, 2010.

Ghazali, Bahri. Pendidikan Pesantren Berwawasan Lingkungan. Jakarta: Pedoman IImu Jaya, 2001.

Gontor:, Pondok Modern. Biografi K.H. Imam Zarkasyi: Dari Gontor Merintis Pesantren Modern. Ponorogo: Gontor Press, 1996.

Gontor:, Pondok Modern. Sejarah Balai Pendidikan Pondok Modern Gontor Indonesia Dari Zaman Wali Ke Zaman Tegalsari. Ponorogo: Gontor Press, 1997.

Haedari, Amin. Masa Depan Pesantren: Dalam Tantangan Modernitas Dan Tantangan Komplesitas Global. Jakarta: IRD Press, 2004.

Halim, A. "Menggali Potensi Ekonomi Pondok Pesantren." In Manajemen Pesantren, edited by Pustaka Pesantren. Yogyakarta: LKIS, 2009.

Harjito. "Studi Potensi Ekonomi Dan Kebutuhan Pondok Pesantren Se Karesidenan Kedu Jawa Tengah." Jurnal 
Fenomena 6, no. 1 (2008): 1-19.

Kirorom, Baroroh. "Pendidikan Formal Di Lingkungan Pesantren Sebagai Upaya Meningkatkan Kualitas Sumber Daya Manusia." Jurnal Ekonomi \& Pendidikan 3, no. 1 (2006): 4252.

M. Ali, Hasan. Kapita Selekta Pendidikan Agama Islam. Jakarta: Pedoman IImu Jaya, 2003.

Madjid, Nurcholis. "Merumuskan Kembali Tujuan Pendidikan Pesantren." In Pergulatan Dunia Pesantren: Membangun Dari Bawah, edited by M. Dawam Rahardjo. Jakarta: P3M, 1985.

Mardiyah. Kepemimpinan Kiyai Dalam Memelihara Budaya Organisasi. Malang: Additya Media Publishing, 2012.

Mas'ud, Abdurrahman. Dinamika Pesantren Dan Madrasah. Yogyakarta: Pustaka Pelajar, 2002.

Masyhud, Khusnurdilo. Manajemen Pondok Pesantren. Jakarta: Diva Pustaka, 2003.

Misdah. "Manajemen Pondok Pesantren: Studi Perbandingan Tiga Pondok Pesantren Di Kalimantan Barat." In 2nd International Seminar on Quality and Affordable Education (ISQAE), 44854, 2013.

Mujamil, Qomar. Manajemen Pendiidikan Islam Strategi Baru Pengelolaan Lembaga Pendidikan Islam. Malang: Erlangga, 2010.

Praja, Juhaya S., and Mukhlisin Muzarie. Pranata Ekonomi Islam: Wakaf. Jawa Barat: STAIC Press, 2009.

Proyek Pembinaan dan Bantuan Kepada Pondok Pesantren. Pedoman Penyelenggaraan Unit Ketrampilan Pondok Pesantren. Jakarta: Ditjen Binbaga Islam Departemen Agama RI, n.d.

Qomar, Mujamil. Pesantren Dari Transformasi Metodologi Menuju 
Demokratisasi Institusi. Jakarta: Erlangga, 2002.

Sanusi, Uci. "Pendidikan Kemandirian Di Pondok Pesantren." Jurnal Pendidikan Agama Islam- Ta'lim 10, no. 2 (2012): 12339.

Sholihin, Mukhlis. "Modernisasi Pendidikan Pesantren." Jurnal Tadris 6, no. 1 (2011): 28-46.

Sugiharti, Diyah Yuli. "Strategi Pengembangan Pondok Pesantren Dalam Membangun Peradaban Muslim Di Indonesia." Jurnal Edukasi 3, no. 1 (2011): 8-37.

Suhartini. "Problem Kelembagaan Pengembangan Ekonomi Pesantren." In Manajemen Pesantren, edited by Pustaka Pesantren. Yogyakarta: LKIS, 2009.

Suharto, Ahmad. Profil Pondok Modern Darussalam Gontor. Ponorogo: Darussalam Press, 2011.

Sukamto. Kepemimpinan Kiyai Dalam Pesantren. Jakarta: Pustaka LP3ES, 1999.

Sulaiman, Irchamni. "Pesantren Mengembangkan Teknologi Tepat Guna Ke Pedesaan." In Pergulatan Dunia Pesantren: Membangun Dari Bawah, edited by M. Dawam Rahardjo. Jakarta: P3M, 1985.

Sumardi, Kamin. "Potret Pendidikan Karakter Di Pondok Pesantren Salafiah." Jurnal Pendidikan Karakter 2, no. 3 (2012): 280-92.

Syarif. Kapita Selekta Pondok Pesantren. Jakarta: Paryu Barkah, 1976.

Syawaludin. Peranan Pengasuh Pondok Pesantren Dalam Mengembangkan Budaya Damai Di Provinsi Gorontalo. Jakarta: Kementrian Agama RI Badan Litbang dan Diklat Puslitbang Kehidupan Keagamaan, 2010.

Untung, Selamet. "Rekonstruksi Manajemen Pendidikan 
Pesantren." Jurnal Forum Tarbiyah 9, no. 2 (2011): 249-60.

"Warta Dunia Pondok Modern Darussalam Gontor Vol. 69." Darussalam Press, 2015.

Zakaria, Gamal Abdul Nasir. "Pondok Pesantren: Changes And Its Futures." Journal of Islamic and Arabic Education 2, no. 2 (2010): 45-52.

Zarkasyi, Imam. "Diktat Public Lecture Introduction Week Darussalam Modern Gontor Islamic Institution, with Some Minor Improvements and Additions From Y ear to Year, Since 1939," n.d.

Zuhri, Saefuddin, Suwendi, Marzuki Wahid, and Said Aqiel Siradj. Pesantren Masa Depan: Wacana Pemberdayaan Dan Transformasi Pesantren. Edited by Said Aqiel Siradj. Bandung: Pustaka Hidayah, 1999. 